\title{
Genetic and Phenotypic Correlations Between Milk Coagulation Properties, Milk Production Traits, Somatic Cell Count, Casein Content, and $\mathrm{pH}$ of Milk
}

\author{
T. Ikonen, S. Morri, A.-M. Tyrisevä, O. Ruottinen, and M. Ojala \\ Department of Animal Science, University of Helsinki, \\ PO Box 28, 00014 Helsinki University, Finland
}

\section{ABSTRACT}

Genetic and phenotypic correlations between milk coagulation properties (MCP: coagulation time and curd firmness), milk yield, fat content, protein content, $\ln$ (somatic cell count) (SCS), casein content, and $\mathrm{pH}$ of milk and heritability of these traits were estimated from data consisting of milk samples of 4664 Finnish Ayrshire cows sired by 91 bulls. In addition, differences in average estimated breeding values (EBV) for the above traits between the cows with noncoagulating (NC) milk and those with milk that coagulated (CO samples) were examined. The estimations were carried out to study the possibilities of indirect genetic improvement of MCP by use of the above characteristics. The genetic and phenotypic correlations between MCP and the milk production traits were low or negligible. The genetic associations between desirable MCP and low SCS were rather strong ( -0.45 to 0.29$)$. Desirable MCP correlated both genetically and phenotypically with low $\mathrm{pH}$ of milk (-0.51 to 0.50 ). The rather high heritability estimates for curd firmness in different forms $(0.22$ to 0.39 ), and the wide variation in the proportion of daughters producing NC milk between the sires (0 to $47 \%$ ) suggested that noncoagulation of milk is partly caused by additive genetic factors. Based on the genetic correlations between curd firmness and SCS and the high EBV for SCS obtained for the cows with NC-milk, it is possible that the loci causing noncoagulation of milk and increasing somatic cell count of milk are closely linked or partly the same. One means to genetically improve MCP and to reduce the occurrence of NC milk could thus be selection for low somatic cell count of milk.

(Key words: genetic correlation, milk coagulation property, noncoagulation of milk, somatic cell count)

Abbreviation key: CO samples = milk samples that coagulated, $\mathbf{M C P}=$ milk coagulation properties, $\mathbf{N C}=$ noncoagulating.

Received April 7, 2003.

Accepted July 18, 2003

Corresponding author: T. Ikonen; e-mail: tiina.ikonen@animal. helsinki.fi.

\section{INTRODUCTION}

Genetic improvement of milk coagulation properties (MCP: milk coagulation time, curd firming time, and curd firmness) would be an effective way to improve the efficiency of cheese production (e.g., Ikonen, 2000). Milk coagulation properties have a clear effect on cheese-making properties of milk; milk that aggregates and forms a firm curd soon after the addition of the clotting enzyme is expected to produce higher DM cheese yields than does milk with poor coagulation properties (Bynum and Olson, 1982; Riddell-Lawrence and Hicks, 1989). The basic conditions for genetic improvement of MCP are good. Much variation exists in these properties, and 30 to $40 \%$ of this variation is additive genetic (e.g., Ikonen et al., 1997, 1999a). In addition, MCP are moderately repeatable (Schaar, 1984; Caroli et al., 1990; Ikonen et al., 1997, 1999a; Tyrisevä et al., 2003). During a lactation, only a few measurements for MCP of a cow would thus be adequate for reliable estimation of breeding values for these properties.

Because current instruments need about $30 \mathrm{~min}$ to measure MCP, measurement of MCP for all cows in milk recording and selection of breeding animals based on these properties are currently impossible. Indirect ways to genetically improve MCP are therefore necessary. An attractive way to indirectly improve MCP would be through selecting for the traits that are measured in routine milk recording (test-day milk yield, fat content, protein content, and SCC) and genetically correlate with MCP. Of the above traits, protein content of milk is of particular interest, because high protein content has been reported to have a favorable phenotypic effect on MCP (e.g., Lucey and Kelly, 1994).

Thus far, genetic correlations between MCP and the traits measured in milk recording have been estimated in only a few studies based on small amounts of data (Lindström et al., 1984; Oloffs et al., 1992; Ikonen et al., 1999a). In addition, in Lindström et al. (1984) and Oloffs et al. (1992), the genetic correlations were estimated by use of a sire model under the least squares procedure, which can not utilize the relationships be- 
tween the animals and can not estimate genetic parameters as reliably as an animal model under a mixed model procedure can. In the above studies, many estimates of the genetic correlations between MCP and milk yield, fat content, protein content, and SCC were unreliable, and in some cases also inconsistent. At the moment, possibilities to genetically improve MCP through selection based on the traits measured in milk recording are thus unknown.

Besides the above traits, casein content and $\mathrm{pH}$ of milk are interesting candidates for indirect genetic improvement of MCP. According to some studies, high casein content (Okigbo et al., 1985; Marziali and NgKwai-Hang, 1986) and low pH of milk (McMahon, 1984; Okigbo et al., 1985) have a favorable phenotypic effect on MCP. Further, of the proteins in milk, only the caseins are utilized in cheese production, whereas the whey proteins are lost in the cheese whey. Improvement of MCP by selecting for high casein content should, on the other hand, be effective enough to cover the additional expenses of casein measurements. In addition, because total protein content and casein content are genetically closely correlated (Hayes et al., 1984), it is possible that selection for high casein content could be carried out through selection for high total protein content.

In Oloffs et al. (1992), the estimates of the genetic correlations between MCP and casein content indicated that selection for high casein content could improve MCP. Because the estimates reported by Oloffs et al. (1992) had high standard errors, reliable estimates of the genetic correlations between MCP and casein content are necessary. According to Lindström et al. (1984), Oloffs et al. (1992), and Ikonen et al. (1999a), desirable MCP correlated genetically with low $\mathrm{pH}$ of milk.

Noncoagulation of milk, i.e., milk does not aggregate and form any curd within 30 to 31 min after addition of the clotting enzyme, seems to be a rather common ( $10 \%)$ phenomenon in the Finnish Ayrshire, the most important dairy breed in Finland (Ikonen et al., 1999a; Tyrisevä et al., 2003). Noncoagulating (NC) milk is poorly suited for cheese production (Ikonen et al. 1999b). The variation in the proportion of daughters producing NC milk between sires observed by Ikonen et al., (1999a) suggests that noncoagulation of milk could in part be genetically controlled. Further estimation of the genetic and environmental factors associated with NC milk is thus useful.

The objective of the present study was to estimate the genetic and phenotypic associations between milk coagulation properties (including noncoagulation of milk) and milk yield, fat content, protein content, SCC, casein content, and $\mathrm{pH}$ of milk.

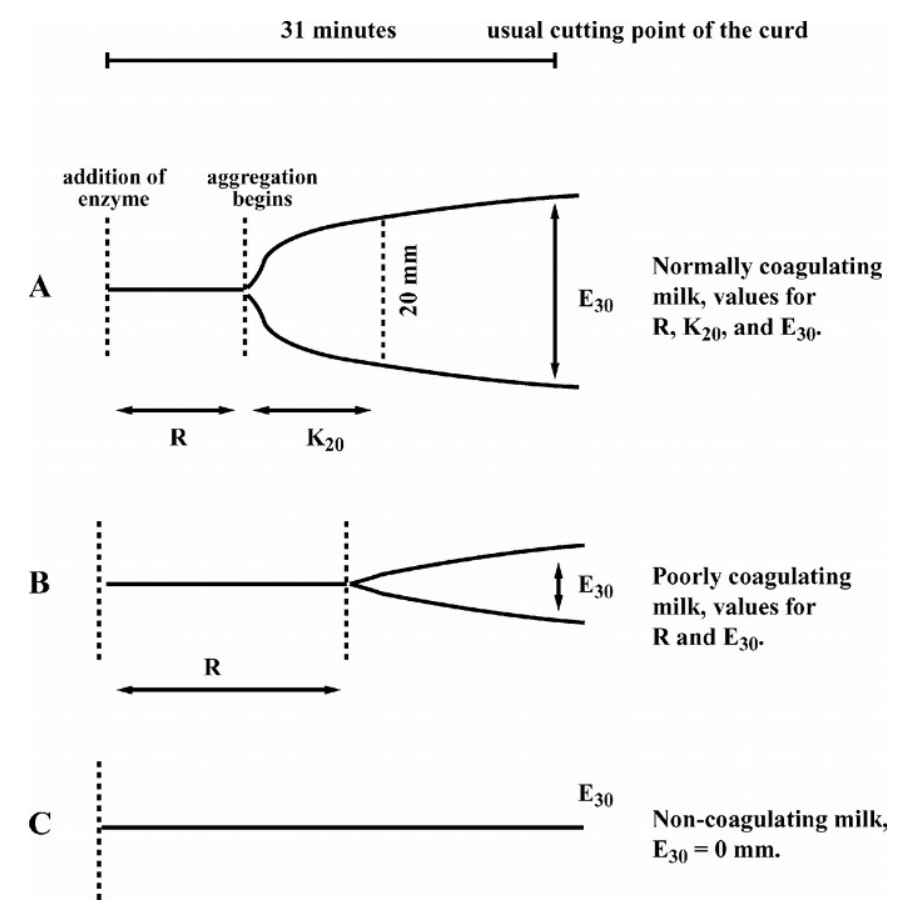

Figure 1. Diagrams for normally coagulating (A), poorly coagulating (B), and noncoagulating $(\mathrm{C})$ milks produced by a milk coagulation meter. The milk coagulation properties calculated from a diagram are: milk coagulation time $(R)$ in minutes, curd firming time $\left(K_{20}\right)$ in minutes, and curd firmness $\left(\mathrm{E}_{30}\right)$ in millimeters.

\section{MATERIALS AND METHODS}

\section{Collection of Data}

During February to May of 1999, 5095 Finnish Ayrshire cows sired by 91 Finnish Ayrshire bulls were sampled once for the measurements of MCP, test-day milk yield, and composition and quality of milk. The cows were located in 693 herds that had at least 20 cows in milk production and sired by the above bulls. The milk samples ( 3 samples per cow) were taken at the same time and in the same manner as samples for milk recording.

\section{Laboratory Analyses and Description of Traits}

One of the milk samples collected from a cow was used to measure coagulation properties and $\mathrm{pH}$ of milk, one to measure gross composition and SCC of milk, and one to measure casein content of milk.

Milk coagulation properties. Enzymatic coagulation of milk is a process of three overlapping steps (Brown and Ernstrom, 1988), which can be described with a diagram produced by a milk-coagulation meter (Figure 1). During the primary, enzymatic phase of coagulation, the clotting enzyme splits $\kappa$-CN at the $\mathrm{Phe}_{105^{-}}$ Met $_{106}$ bond into para- $\kappa-\mathrm{CN}$ and a macropeptide. Be- 
cause of splitting of $\kappa$ - $\mathrm{CN}$, casein begins to aggregate (second phase of coagulation). Milk coagulation time (R) describes the time from the addition of the clotting enzyme to the beginning of aggregation (Figure 1). During the third step of coagulation, aggregated casein micelles form a more or less firm gel. Curd firming time $\left(\mathrm{K}_{20}\right)$ describes the time needed until the curd is firm enough to be cut, i.e., the width of the diagram equals $20 \mathrm{~mm}$ (Figure 1). Curd firmness $\left(\mathrm{E}_{30}\right)$ describes the firmness of the curd (the width of the diagram) $31 \mathrm{~min}$ after addition of the clotting enzyme (Figure 1). In cheese production, milk that aggregates quickly (short coagulation time) and forms a firm curd soon after the addition of the clotting enzyme (short curd firming time and a high value for curd firmness) is desirable.

The milk coagulation properties of the milk samples (10 ml) were measured for $31 \mathrm{~min}$ by a Computerized Renneting Meter (Polo Trade, Monselice, Italy) at $35^{\circ} \mathrm{C}$ with $200 \mu \mathrm{l}$ of rennet (Hansen standard 190, Pacovis Amrein AG, Bern, Switzerland) diluted in sodium acetate buffer (3:100). The $\mathrm{pH}$ of milk was measured with a $744 \mathrm{pH}$ Meter (Metrohm, Herisau, Switzerland). The determinations were conducted at the Department of Animal Science, University of Helsinki. Milk coagulation properties are measured for $31 \mathrm{~min}$ because in cheese production, the curds are cut about 30 min after the addition of the clotting enzyme.

Thirty percent of the milk samples did not produce a value for curd firming time in 31 min, i.e., the width of the diagram was less than $20 \mathrm{~mm}$ for the samples (Figure 1B). In cheese production, these poorly coagulating samples would not reach the firmness needed to be able to properly cut the curds. Because of the high proportion of cows with no value for curd firming time, which trait correlated very closely with coagulation time and firmness of the curd (data not shown), exclusion of curd firming time from the statistical analyses was justified. Consequently, the traits describing coagulation properties of milk used in the present study were coagulation time and curd firmness.

Composition and quality of milk. Fat content, protein content (Milko Scan 605, N. Foss \& Co. A/S, Hillerød, Denmark), casein content (Milko Scan FT 120, Foss Electric A/S, Hillerød, Denmark), and SCC (Fossomatic 360, N. Foss \& Co. A/S) of milk were measured at the laboratories of Valio Ltd. (Helsinki, Finland). Because the distribution for SCC was not normal, the SCC were transformed to natural logarithm of SCC, called SCS.

\section{Data Used in Statistical Analyses}

Of the 5095 cows with observations, 431 were excluded from the statistical analyses for various reasons (e.g., the milk samples of the cows were collected within the first $5 \mathrm{~d}$ after calving, or the cows had no or false information on pedigree, parity, or lactation stage). Consequently, the data used in the statistical analyses consisted of observations of 4664 Finnish Ayrshire cows sired by 91 bulls. The number of daughters per bull ranged from 17 to 271 .

\section{Statistical Analyses}

Genetic and phenotypic parameters. Heritability of MCP and genetic and phenotypic correlations between these properties and other traits studied were estimated by use of a univariate and a bivariate model:

Model 1:

$$
\begin{gathered}
\mathrm{y}_{\mathrm{ijklmn}}=\mu+\mathrm{Pa}_{\mathrm{i}}+\mathrm{Ls}_{\mathrm{j}}+\text { Age }_{\mathrm{k}}+\text { Unit }_{\mathrm{l}} \\
+\operatorname{Herd}_{\mathrm{m}}+\operatorname{Add}_{\mathrm{n}}+\varepsilon_{\mathrm{ijklmn}}
\end{gathered}
$$

where

$$
\begin{aligned}
\mathrm{y}_{\mathrm{ijk} k m n}= & \text { milk coagulation time and curd firmness, } \\
\mu= & \text { a general mean, } \\
\mathrm{Pa}_{\mathrm{i}}= & \text { fixed effect of parity class } \mathrm{i}(\mathrm{i}=1 \text { to } 2), \\
\mathrm{Ls}_{\mathrm{j}}= & \text { fixed effect of lactation stage class } \mathrm{j}(\mathrm{j}=1 \text { to } \\
& 12), \\
\mathrm{Age}_{\mathrm{k}}= & \text { fixed effect of sample age class } \mathrm{k}(\mathrm{k}=1 \text { to } \\
& 11), \\
\mathrm{Unit}_{\mathrm{l}}= & \text { fixed effect of measuring unit } \mathrm{l} \text { of a coagula- } \\
& \text { tion meter }(\mathrm{l}=1 \text { to } 20), \\
\mathrm{Herd}_{\mathrm{m}}= & \text { random effect of herd } \mathrm{m}, \mathrm{N}\left(\mathbf{0}, \mathbf{I} \sigma_{\mathrm{c}}^{2}\right), \\
\operatorname{Add}_{\mathrm{n}}= & \operatorname{random} \text { additive genetic effect of animal } \mathrm{n}, \\
& \mathrm{N}\left(\mathbf{0}, \mathbf{A} \sigma_{\mathrm{a}}^{2}\right), \\
\varepsilon_{\mathrm{ijk} k m n}= & \text { random residual effect, } \mathrm{N}\left(\mathbf{0}, \mathbf{I} \sigma^{2}\right) .
\end{aligned}
$$

Except for the effect of a measuring unit, the model used for $\mathrm{pH}$ included the same effects as the above model. For test-day milk yield, fat content, protein content, casein content, and SCS, the effect of a measuring unit and that of the age of a milk sample were excluded from the statistical model.

Parity was grouped into two classes: first and second to third parities. Only 92 cows had calved three times. Lactation stage was grouped into 12 classes: 5 to 15 , 16 to 30,31 to 60,61 to 90,91 to 120,121 to 150,151 to 180,181 to 210,211 to 240,241 to 270,271 to 300 , and $>300 \mathrm{~d}$ after calving. Age of the milk samples at the time of measurement (for MCP and $\mathrm{pH}$ ) ranged from 0 to $27 \mathrm{~d}$, and it was grouped into 11 classes. Except for the first (0 to $2 \mathrm{~d}$ ) and last (12 to $27 \mathrm{~d}$ ) class, the age of the milk samples was grouped at 1-d intervals. The 2 coagulation meters included altogether 20 measuring units, and each unit was treated as one 
Table 1. Means and variation for the traits studied.

\begin{tabular}{lcccccc}
\hline Trait & $\begin{array}{l}\text { No. of } \\
\text { obs. }\end{array}$ & Mean & SD $^{1}$ & Min & Max & CV-\% \\
\hline Coagulation time of samples that coagulated, min & 4038 & 11.8 & 5.5 & 0.4 & 31.0 & 47 \\
Curd firmness of all samples, ${ }^{2}$ mm & 4664 & 24.0 & 13.3 & 0.0 & 58.0 & 55 \\
Curd firmness of samples that coagulated, mm & 4046 & 27.6 & 10.0 & 1.0 & 58.0 & 36 \\
Curd firmness as a binary trait ${ }^{3}$ & 4664 & 0.9 & 0.3 & 0 & 1 & 33 \\
Test-day milk yield, kg & 4647 & 24.3 & 6.9 & 6.0 & 54.8 & 28 \\
Fat content, \% & 4370 & 4.39 & 0.77 & 1.05 & 7.97 & 18 \\
Protein content, \% & 4370 & 3.39 & 0.35 & 2.40 & 6.03 & 10 \\
Casein content, \% & 4546 & 2.78 & 0.27 & 1.88 & 4.62 & 10 \\
SCS ${ }^{4}$ & 4381 & 4.02 & 1.21 & 0.00 & 8.38 & 30 \\
pH & 4661 & 6.65 & 0.06 & 5.72 & 7.13 & 1 \\
\hline & & & & & & \\
${ }^{1}$ Standard deviation. & & & & & \\
${ }^{2}$ Samples that coagulated (n = 4046) plus noncoagulating samples (n = 618). & & & \\
${ }^{3}$ For the samples that coagulated the value for the trait was 1, and for noncoagulating samples it was 0. \\
${ }^{4}$ Somatic cell score, ln(somatic cell count).
\end{tabular}

class. The number of milk samples measured per one unit ranged from 196 to 258 .

For the bivariate models, the covariances among the herd effects, among the additive genetic effects, and among the residual effects for traits $i$ and $j$ were assumed to be: $\mathbf{I} \sigma_{\mathrm{cij}}, \mathbf{A} \sigma_{\mathrm{aij}}$, and $\mathbf{I} \sigma_{\varepsilon \mathrm{ij}}$, respectively. Covariances among the herd, additive genetic and residual effects were assumed to equal zero.

The (co)variance components for the random effects in the models used to calculate heritabilities and genetic and phenotypic correlations were estimated from the data by use of the REML-VCE package (Neumaier and Groeneveld, 1998). Solutions for the fixed and random effects in the models were obtained by use of the PEST package (Groeneveld, 1990). The statistical significance of the fixed effects was tested using the $F$-test provided by the PEST package.

The pedigree information in the relationship matrix A for the cows with observations included parents and grandparents of the cows. The total number of animals in the statistical analyses was 14,010.

Cows with noncoagulating milk. About $13 \%$ ( $\mathrm{n}=$ 618 ) of the milk samples in the data were noncoagulating, i.e., they did not aggregate and form any curd within $31 \mathrm{~min}$ (Figure 1C). Because of the high occurrence of noncoagulation of milk, which is an undesirable and yet a rather unknown phenomenon, it was considered necessary to examine the EBV for the various milk production traits obtained for the cows with NC milk. This information could be useful when considering various possibilities to decrease the occurrence of NC milk. Consequently, average EBV for milk yield, fat content, protein content, SCS, casein content, and $\mathrm{pH}$ were calculated for the cows with NC milk $(\mathrm{n}=618)$ as well for those with milk that coagulated (CO samples). Cows with $\mathrm{CO}$ samples were grouped into 4 classes according to their phenotypic values for curd firmness: 1 to 19
( $\mathrm{n}=728), 20$ to $29(\mathrm{n}=1498), 30$ to $39(\mathrm{n}=1395)$, and 40 to $58 \mathrm{~mm}(\mathrm{n}=425)$. Only the EBV of the cows with observations were utilized in the calculations.

\section{RESULTS}

\section{Means and Variation}

Of the 4664 milk samples, 4046 began to aggregate within 31 min after addition of the clotting enzyme and thus obtained a value both for coagulation time (except for 8 samples for which the coagulation meter did not report the value for $R$ ) and curd firmness (Table 1 ). Consequently, $13 \%(n=618)$ of the milk samples did not aggregate and form any curd within 31 min after addition of the enzyme. These NC milks obtained no value for coagulation time (or curd firming time), and the value for curd firmness was equal to 0 (Figure 1C). The NC milks formed a peak at the left-hand end of the distribution for curd firmness (Figure 2).

Because of the high proportion of NC milks in the data, curd firmness was considered in different ways: 1) curd firmness of all milk samples in the data $\left(E_{30} \geq\right.$ $0), 2$ ) curd firmness of $\mathrm{CO}$ samples, i.e., samples that coagulated in $31 \mathrm{~min}\left(\mathrm{E}_{30}>0\right)$, and 3 ) curd firmness as a binary trait (CO milks vs. NC milks) (Table 1). Because of the high proportion of NC milks, the difference in average curd firmness between all samples and $\mathrm{CO}$ samples was rather large, about $4 \mathrm{~mm}$ (Table 1). Within the daughter groups of the 91 bulls, the proportion of cows producing NC milk ranged widely, from 0 to $47 \%$. Consequently, for the most extreme bulls, almost half of their daughters produced milk that is poorly suited for cheese production.

Variation in MCP was wider than that in milk yield, or in composition characteristics and SCS of milk (Table 1). 
Table 2. Effect of parity on the traits studied.

\begin{tabular}{|c|c|c|c|}
\hline \multirow[b]{2}{*}{ Trait } & \multicolumn{2}{|c|}{ Parity } & \multirow[b]{2}{*}{$F$-test } \\
\hline & $\begin{array}{c}1 \\
\mathrm{~N}^{1}=2806\end{array}$ & $\begin{array}{c}2 \text { to } 3 \\
\mathrm{~N}^{1}=1858\end{array}$ & \\
\hline Coagulation time of samples that coagulated, min & 0 & $-0.2 \pm 0.2$ & 0.357 \\
\hline Curd firmness of all samples, ${ }^{2} \mathrm{~mm}$ & 0 & $1.8 \pm 0.5$ & $<0.001$ \\
\hline Curd firmness of samples that coagulated, $\mathrm{mm}$ & 0 & $0.4 \pm 0.4$ & 0.357 \\
\hline Test-day milk yield, kg & 0 & $4.0 \pm 0.2$ & $<0.001$ \\
\hline Fat content, $\%$ & 0 & $-0.06 \pm 0.03$ & 0.037 \\
\hline Protein content, $\%$ & 0 & $0.00 \pm 0.01$ & 0.885 \\
\hline Casein content, \% & 0 & $-0.03 \pm 0.01$ & 0.001 \\
\hline $\mathrm{SCS}^{3}$ & 0 & $0.28 \pm 0.04$ & $<0.001$ \\
\hline $\mathrm{pH}$ & 0 & $0.02 \pm 0.00$ & $<0.001$ \\
\hline
\end{tabular}

${ }^{1}$ Maximum number of milk samples in the parity class.

${ }^{2}$ Samples that coagulated $(\mathrm{n}=4046)$ plus noncoagulating samples $(\mathrm{n}=618)$.

${ }^{3}$ Somatic cell score, $\ln$ (somatic cell count).

\section{Environmental Factors Affecting Traits}

Parity. The values for curd firmness were somewhat lower for the primiparous cows than for those that had calved 2 or 3 times (Table 2). The main reason for this difference was the higher proportion of cows producing $\mathrm{NC}$ milk among the primiparous cows (17\%) than among the other cows (9\%). When only CO samples were analyzed, parity had no statistically significant effect on curd firmness (Table 2). Milk yield, SCS, and $\mathrm{pH}$ increased and fat content decreased with parity (Table 2). Protein content was not affected by parity, but casein content decreased with parity.

Lactation stage. The effect of lactation stage was strong $(P<0.001)$ on all characteristics studied (Figure 3). Milk coagulation properties were at their best at the very beginning of lactation, deteriorated rather quickly

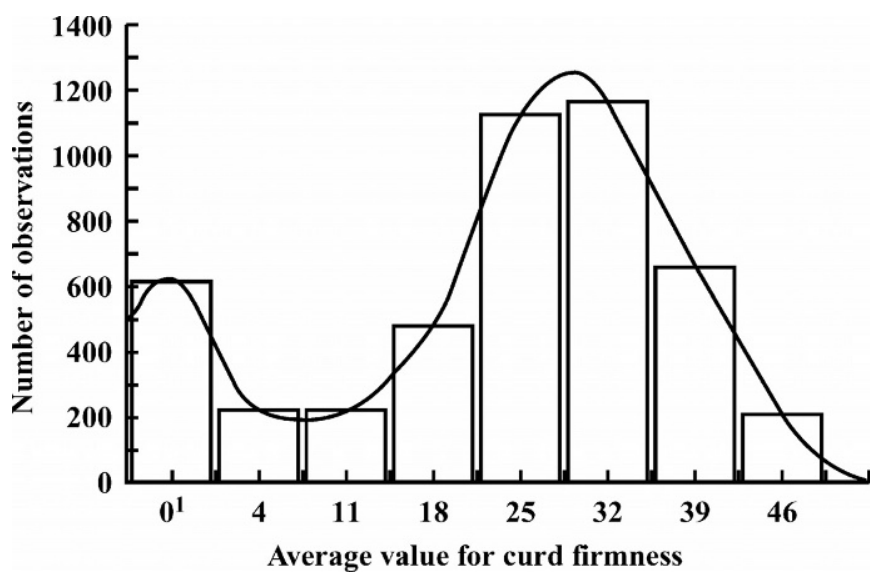

Figure 2. Distribution of the values for curd firmness. The mean curd firmness is presented for each class. Except for the noncoagulating milks and the class with the highest values for curd firmness $\left(\mathrm{E}_{30}=43\right.$ to 58$)$, the range of the values for curd firmness within a class is $7 \mathrm{~mm}$.

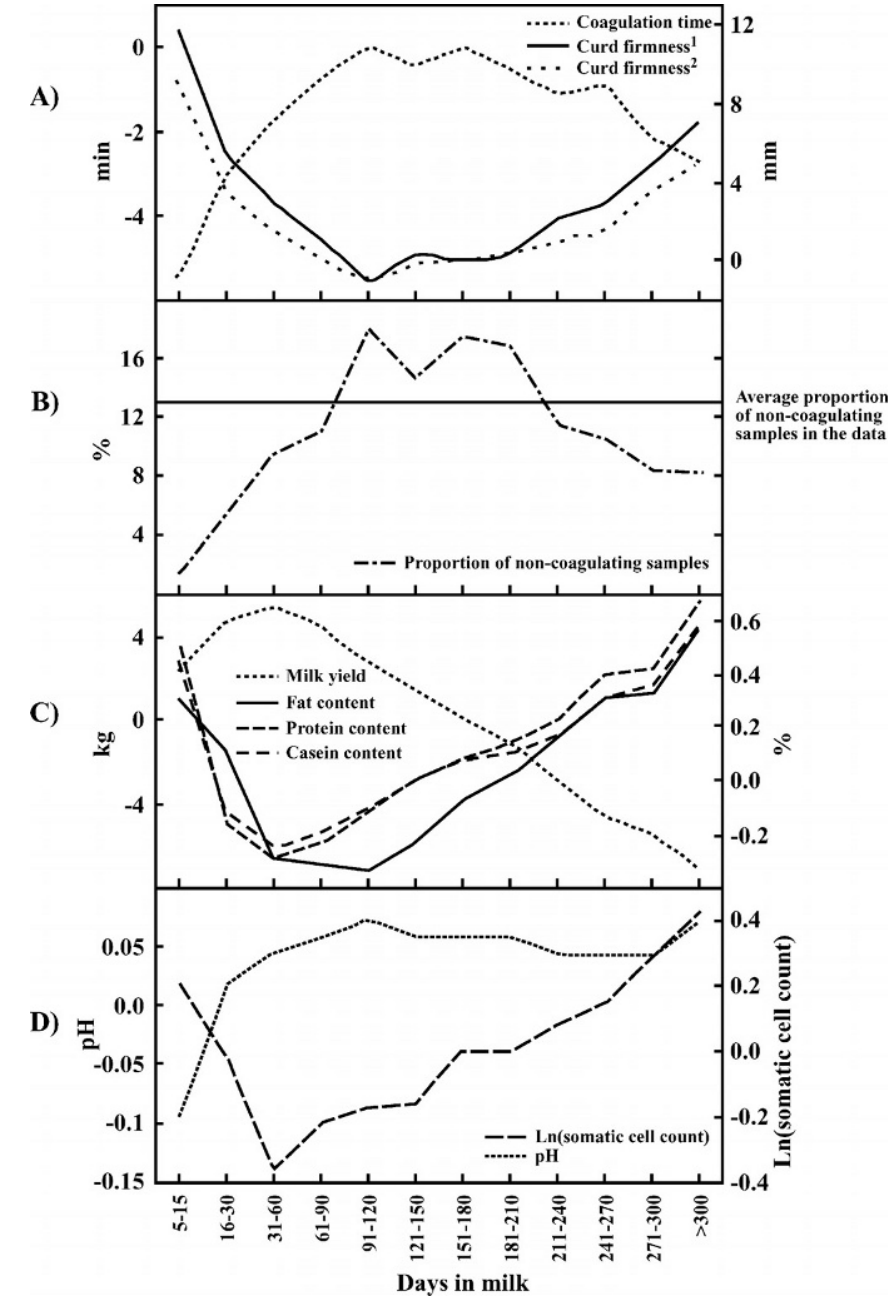

Figure 3. Effect of lactation stage on milk coagulation properties (A), proportion of noncoagulating milk (B), and yield, composition (C), and quality (D) of milk. All ${ }^{1}$ samples (samples that coagulated plus noncoagulating samples), samples ${ }^{2}$ that coagulated. 
Table 3. Estimates of heritability and herd effects with standard errors for the traits studied.

\begin{tabular}{|c|c|c|c|c|}
\hline \multirow[b]{2}{*}{ Trait } & \multicolumn{2}{|c|}{ Herd effect ${ }^{1}$} & \multicolumn{2}{|c|}{ Heritability } \\
\hline & Est. & $\mathrm{SE}$ & Est. & $\mathrm{SE}$ \\
\hline Coagulation time of samples that coagulated, min & 0.05 & 0.01 & 0.28 & 0.03 \\
\hline Curd firmness of all samples, ${ }^{2} \mathrm{~mm}$ & 0.05 & 0.01 & 0.39 & 0.04 \\
\hline Curd firmness of samples that coagulated, $\mathrm{mm}$ & 0.06 & 0.01 & 0.22 & 0.03 \\
\hline Curd firmness as a binary trait, ${ }^{3} \mathrm{~mm}$ & 0.02 & 0.01 & 0.26 & 0.03 \\
\hline Test-day milk yield, $\mathrm{kg}$ & 0.25 & 0.01 & 0.13 & 0.02 \\
\hline Fat content, \% & 0.26 & 0.01 & 0.18 & 0.03 \\
\hline Protein content, $\%$ & 0.15 & 0.01 & 0.29 & 0.04 \\
\hline Casein content, \% & 0.16 & 0.01 & 0.35 & 0.04 \\
\hline $\mathrm{SCS}^{3}$ & 0.08 & 0.01 & 0.06 & 0.02 \\
\hline $\mathrm{pH}$ & 0.15 & 0.01 & 0.38 & 0.04 \\
\hline
\end{tabular}

during the first 3 mo of lactation, and were at their worst during midlactation (Figure 3A). During the last third of lactation, MCP improved again, but did not reach the level observed at the beginning of lactation. The proportion of NC milks was at its lowest at the beginning of lactation, and clearly at its highest during midlactation (Figure 3B).

The changes in milk yield with lactation stage did not follow those in MCP (Figure 3C). Milk yield reached its peak 2 mo after calving and then declined for the rest of lactation. Fat content, protein content, and casein content of milk were high at the very beginning of lactation, reached their lowest values during the first third of lactation, and were already increasing during midlactation when MCP were at their poorest, and proportion of NC milks was at its highest. During the last third of lactation, contents of fat, protein, and casein increased steeply.

Somatic cell score was at its highest at the same time as MCP were at their best, i.e., at the beginning and at the end lactation (Figure 3D). Except for the very end of lactation, the changes in $\mathrm{pH}$ of milk were similar to those in coagulation time and proportion of NC milks; $\mathrm{pH}$ increased steeply during the first third of lactation, and stayed high for the rest of lactation (Figure 3D).

Age of the sample. The age of the milk samples had no statistically significant effect on milk coagulation time (data not shown). The values for curd firmness decreased $(P<0.001)$, and the proportion of NC milks increased (from $9 \%$ to about $17 \%$ ) linearly with the age of the samples. The $\mathrm{pH}$ of milk clearly dropped at 2 stages: in the samples that were $5 \mathrm{~d}$ old and in those that were $11 \mathrm{~d}$ old at the time of measurement $(P<0.001)$.

Measuring unit. No statistically significant differences existed in milk coagulation times analyzed by the 20 measuring units. The differences in the values for curd firmness between the measuring units were relatively large $(P<0.001)$, at maximum $10 \mathrm{~mm}$. The proportion of NC milks in the total amount of samples measured by a unit ranged from 8 to $19 \%$.

Herd. The variation in MCP between the herds was of the same magnitude as that in SCS, but was clearly lower than that in milk yield, fat content, protein content, casein content, and $\mathrm{pH}$ (Table 3). Consequently, the differences in feeding and management practices between the farms had only a small effect on the variation in MCP.

\section{Heritability Estimates}

About $30 \%$ of the variation in coagulation time and $40 \%$ of that in curd firmness of all samples was additive genetic (Table 3). The heritability estimate for curd firmness of $\mathrm{CO}$ samples was $0.17 \mathrm{U}$ lower than that of all samples, and the heritability estimate for curd firmness as a binary trait was slightly higher than that of CO samples (Table 3 ). The heritability estimates for protein content, casein content, and $\mathrm{pH}$ were of the same magnitude, and those for milk yield, fat content, and SCS were lower than the estimates for MCP (Table 3 ).

\section{Correlations}

Genetic correlations. Milk coagulation time and curd firmness were genetically closely correlated; short coagulation time correlated with high value for curd firmness (Table 4). Short coagulation time correlated slightly with low protein and casein contents, whereas the correlations between curd firmness and the proteins were negligible (Table 4). Of the other traits measured in milk recording, only SCS was genetically associated 
IKONEN ET AL.

Table 4. Phenotypic (lower triangle) and genetic (upper triangle) correlations between the traits studied. Standard errors of the genetic correlations are presented as subscripts.

\begin{tabular}{|c|c|c|c|c|c|c|c|c|c|}
\hline Traits & $\mathrm{R}$ & $\mathrm{CF}_{\text {all }}$ & $\mathrm{CF}_{c o}$ & Mkg & F-\% & P-\% & $\mathrm{Cn}-\%$ & SCS & $\mathrm{pH}$ \\
\hline $\mathrm{R}^{1}$ & & $-0.97_{0.01}$ & $-0.93_{0.02}$ & $0.12_{0.10}$ & $0.08_{0.07}$ & $0.22_{0.08}$ & $0.16_{0.09}$ & $0.29_{0.12}$ & $0.50_{0.07}$ \\
\hline $\mathrm{CF}_{\text {all }}^{2}$ & -0.92 & & - & $-0.12_{0.09}$ & $0.02_{0.09}$ & $-0.02_{0.08}$ & $0.03_{0.08}$ & $-0.45_{0.09}$ & $-0.32_{0.08}$ \\
\hline $\mathrm{CF}_{c o}{ }^{3}$ & -0.87 & - & & $-0.07_{0.10}$ & $0.02_{0.10}$ & $-0.07_{0.09}$ & $-0.01_{0.08}$ & $-0.33_{0.12}$ & $-0.51_{0.07}$ \\
\hline $\mathrm{Mkg}^{4}$ & 0.02 & -0.02 & -0.02 & & $-0.28_{0.10}$ & $-0.39_{0.09}$ & $-0.38_{0.09}$ & $-0.07_{0.15}$ & $0.02_{0.10}$ \\
\hline F- $\%{ }^{5}$ & -0.01 & 0.02 & 0.03 & -0.25 & & $0.63_{0.06}$ & $0.69_{0.05}$ & $0.37_{0.13}$ & $0.02_{0.07}$ \\
\hline P- $\% 6$ & 0.02 & 0.06 & 0.12 & -0.27 & 0.30 & & $0.92_{0.01}$ & $0.02_{0.14}$ & $-0.12_{0.03}$ \\
\hline $\mathrm{Cn}-\%{ }^{7}$ & 0.06 & 0.07 & 0.14 & -0.22 & 0.39 & 0.91 & & $0.06_{0.13}$ & $-0.20_{0.09}$ \\
\hline $\mathrm{SCS}^{8}$ & 0.00 & -0.01 & -0.04 & -0.13 & 0.07 & 0.07 & 0.00 & & $0.26_{0.12}$ \\
\hline pH & 0.29 & -0.18 & -0.26 & -0.08 & -0.04 & -0.11 & -0.14 & 0.16 & \\
\hline
\end{tabular}

${ }^{1}$ Milk coagulation time of samples that coagulated.

${ }^{2}$ Curd firmness of all milk samples [samples that coagulated $(\mathrm{n}=4046)$ plus noncoagulating samples $(\mathrm{n}=$ 618)].

${ }^{3}$ Curd firmness of milk samples that coagulated.

${ }^{4}$ Test-day milk yield, $\mathrm{kg}$.

${ }^{5}$ Fat content of milk, \%.

${ }^{6}$ Protein content of milk, \%.

${ }^{7}$ Casein content of milk, \%.

${ }^{8}$ Somatic cell score, $\ln$ (somatic cell count).

with MCP. Short coagulation time and good firmness of the curd correlated with low SCS (Table 4). The correlation between curd firmness of all samples and SCS was somewhat higher than that between curd firmness of CO samples and SCS (Table 4). Desirable MCP correlated with low $\mathrm{pH}$ of milk (Table 4). The correlation between curd firmness of all milk samples and $\mathrm{pH}$ was lower than that between curd firmness of $\mathrm{CO}$ samples and $\mathrm{pH}$ (Table 4).

Phenotypic correlations. Milk coagulation time and curd firmness were phenotypically closely correlated (Table 4). The correlations between MCP and the traits measured in milk recording and casein content were negligible. Desirable MCP correlated with low $\mathrm{pH}$ of milk.

\section{EBV for Milk Production Traits for Cows with NC Milk}

No differences existed in the average EBV for milk yield for the cows with $\mathrm{NC}$ milk and for those with $\mathrm{CO}$ samples (Figure 4). The average EBV for fat content for the cows with NC milk was of the same magnitude as for most other cows. Only the cows with the highest values for curd firmness $\left(\mathrm{E}_{30}=40\right.$ to $58 \mathrm{~mm}$ ) had somewhat higher average EBV for fat content than had the cows with NC milk.

The cows with NC milk had higher average EBV for protein content and casein content than had the cows with poorly $\left(\mathrm{E}_{30}=1\right.$ to 19$)$ or moderately $\left(\mathrm{E}_{30}=20\right.$ to 29) coagulating milk (Figure 4 ). The cows with high values for curd firmness had as high $\left(\mathrm{E}_{30}=30\right.$ to 39) or higher $\left(\mathrm{E}_{30}=40\right.$ to 58$)$ average EBV for protein and casein than did the cows with NC milk.
The cows with NC milk had the highest average EBV for SCS, and the cows with the highest values for curd firmness had the lowest (Figure 4). The average EBV for $\mathrm{pH}$ for the cows with $\mathrm{NC}$ milk was lower than that for the cows with poorly coagulating milk $\left(\mathrm{E}_{30}=1\right.$ to 19) but was higher than those for the cows with moderately or well-coagulating milk (Figure 4).

\section{DISCUSSION}

\section{Correlations}

Genetic correlations. Except for the weak correlations between short coagulation time and low protein and casein contents, MCP did not correlate genetically with milk production traits. Genetic nonindependence between MCP and milk yield was also reported by Ikonen et al. (1999a). In Oloffs et al. (1992), the rather unreliable estimates indicated that MCP would not correlate with milk yield (Friesian cows), or that desirable MCP would correlate with high milk yield (Angler cows).

In the literature, the estimates for the genetic correlations between MCP and protein and casein contents vary. In Lindström et al. (1984), short coagulation time correlated with high protein content. In the other studies, short coagulation time correlated with low protein content (Oloffs et al., 1992, for Friesian cows; Ikonen et al., 1999a), or coagulation time and protein content did not correlate (Oloffs et al., 1992, for Angler cows). In Oloffs et al. (1992), high values for curd firmness correlated with high protein and casein contents, whereas in Ikonen et al. (1999a), high values for curd 


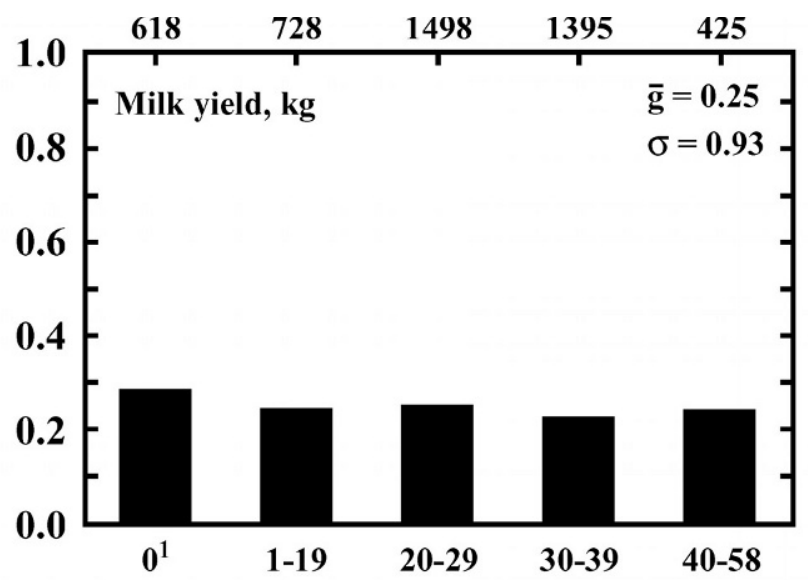

Phenotypic value for curd firmness

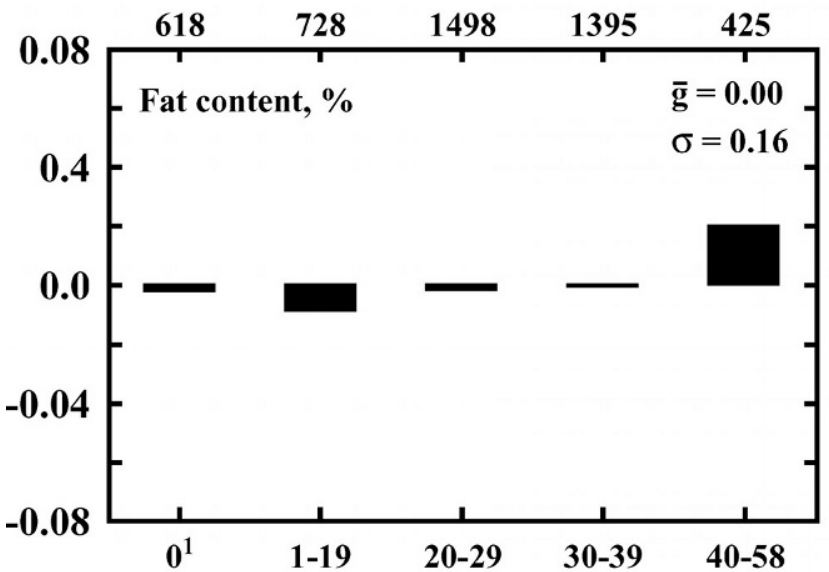

Phenotypic value for curd firmness

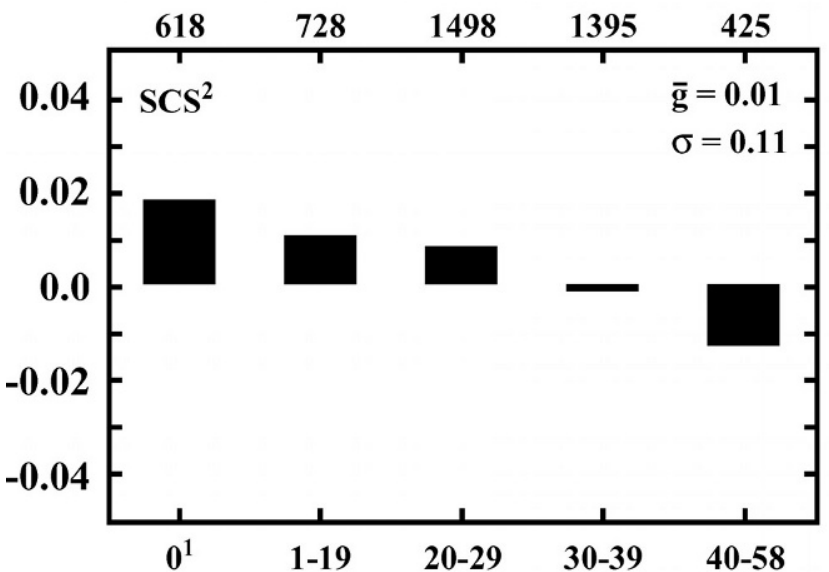

Phenotypic value for curd firmness

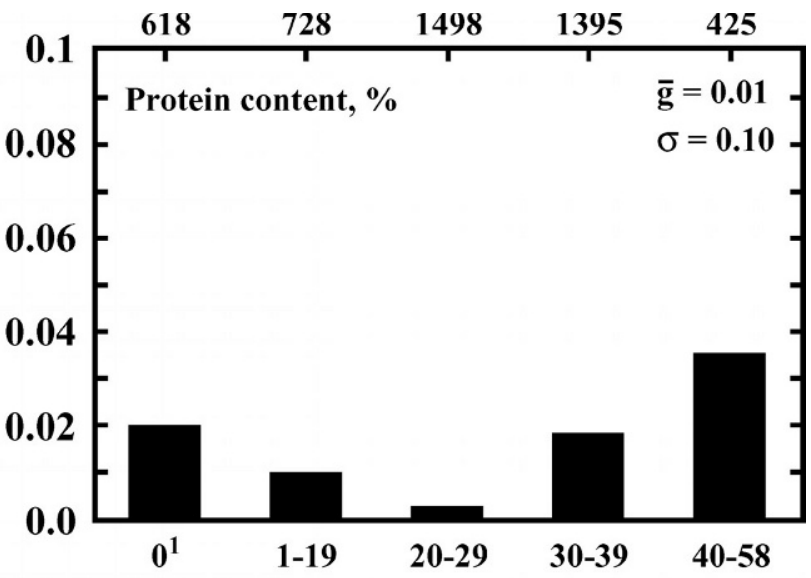

Phenotypic value for curd firmness

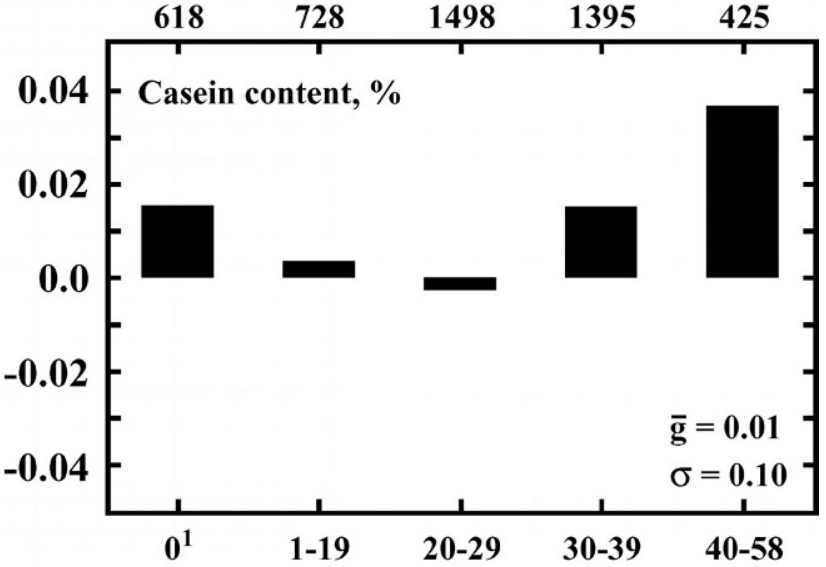

Phenotypic value for curd firmness

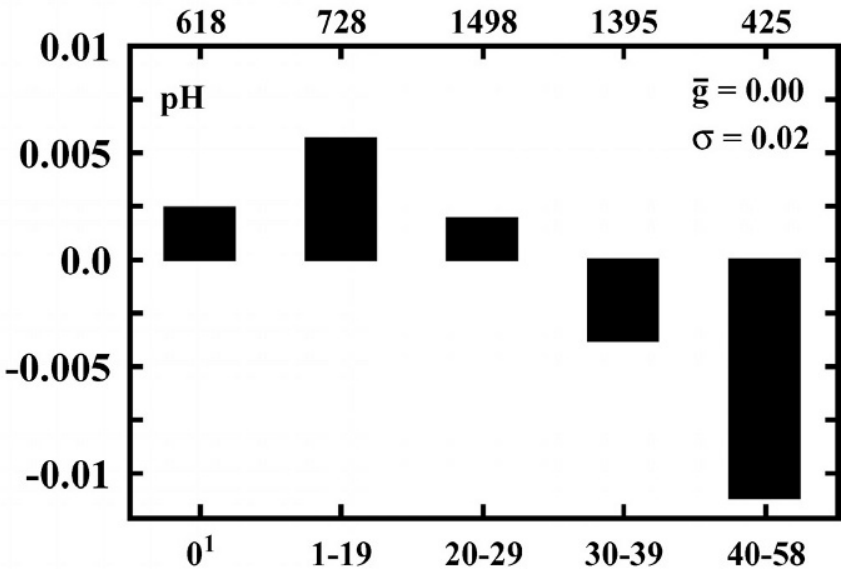

Phenotypic value for curd firmness

Figure 4. Average EBV for the various milk production traits for the cows with noncoagulating ${ }^{1}$ milk and for those with milk that coagulated (grouped into four classes according to the phenotypic value for curd firmness). Average $(\overline{\mathrm{g}})$ and standard deviation $(\sigma)$ of the EBV are presented for each trait. Vertical scale of the graphs is equal to about one standard deviation of the EBV of the corresponding trait. Number of milk samples in each group of the cows is presented on the top of each graph. Somatic ${ }^{2}$ cell score, $\ln ($ somatic cell count). 
firmness correlated with low protein and casein contents.

The genetic correlations between MCP and SCS, as well as those between MCP and $\mathrm{pH}$ were strong. The genetic correlations between MCP and SCS estimated in this study were higher than those presented by Ikonen et al. (1999a). The correlation between desirable $\mathrm{MCP}$ and low $\mathrm{pH}$ of milk observed in this study was also reported by Lindström et al. (1984), Oloffs et al. (1992), and Ikonen et al. (1999a).

Phenotypic correlations. The phenotypic correlations between MCP and the traits measured in milk recording and casein content were negligible. Desirable MCP correlated with low $\mathrm{pH}$ of milk. In the literature, phenotypic correlations between milk coagulation time and milk production traits have been estimated by Lindström et al. (1984) only. In Lindström et al. (1984), milk coagulation time and protein content did not correlate, but short coagulation time correlated with high fat content and low $\mathrm{pH}$ of milk.

\section{Noncoagulating Milk}

Both environmental and genetic factors were associated with noncoagulation of milk. Production of NC milk was most probable among primiparous cows and cows at their midlactation. Changes in composition or quality of milk with parity or lactation stage could not unambiguously explain the high occurrence of NC milk among these cows (Figure 3).

The higher heritability estimate for curd firmness of all milk samples (CO samples plus NC samples) than for curd firmness of $\mathrm{CO}$ samples as well as the high heritability estimate for curd firmness as a binary trait (Table 3) suggest that noncoagulation of milk is partly caused by additive genetic factors. In addition, the wide variation in the proportion of daughters producing $\mathrm{NC}$ milk among the daughter groups of the bulls (0 to 47\%) supports this assumption. This kind of variation was also reported by Ikonen et al. (1999a). Further, the rather high genetic correlation between curd firmness of all samples and SCS (Table 4) as well as the high EBV for SCS obtained for the cows with NC milk (Figure 4) suggest that the loci causing noncoagulation of milk and increasing SCC of milk are closely linked or partly the same.

\section{Indirect Genetic Improvement of Milk Coagulation Properties}

Based on the genetic correlations estimated in this study, genetic improvement of MCP by use of information on milk yield, fat content, protein content, and casein content of milk would be impossible. Further, even though the cows with the highest phenotypic values for curd firmness had the highest average EBV for protein content and casein content, the cows with NC milk also had high average EBV for the proteins (Figure 4). Selection for high protein or casein content could thus on the one hand improve MCP but on the other hand maintain noncoagulation of milk, which would hinder the use of these traits for genetic improvement of MCP.

Selection for low SCC and low $\mathrm{pH}$ of milk would have a favorable effect on MCP (Table 4). Selection for low SCC could also reduce the occurrence of NC milk (Figure 4). Because of lack of suitable instruments to measure $\mathrm{pH}$ of milk in milk recording, genetic improvement of MCP by use of information on $\mathrm{pH}$ is currently impossible. Of the various traits studied, SCC is thus the only trait that could be utilized to genetically improve MCP.

At the moment, the most important breeding objectives of the Finnish dairy cattle are high production of protein and fat, high protein content of milk, good fertility, and good health and conformation of udder (with relative weights of 1.0, 0.3, 0.3, 0.4, 0.3, and 0.5, respectively, in the total merit index of breeding bulls). In Finland, dairy cattle breeding based on the present objectives should thus have no strong unfavorable effect on MCP.

\section{CONCLUSIONS}

Based on the genetic associations between the milk coagulation properties and the various traits studied, one way to genetically improve the milk coagulation properties and to reduce the occurrence of noncoagulating milk could be selection for low SCC in milk.

\section{ACKNOWLEDGMENTS}

Kirsti Ilonen and Kimmo Saarinen from Valio Ltd. and Taina Malmsten from Department of Animal Science, University of Helsinki, are warmly thanked for their contribution in the collection and laboratory analyses of the data.

\section{REFERENCES}

Brown, R. J., and C. A. Ernstrom. 1988. Milk clotting enzymes and cheese chemistry. Part I. Milk clotting enzymes. Pages 609-633 in Fundamentals of Dairy Chemistry. 3rd ed. N. P. Wong, R. Jenness, M. Keeney, and E. H. Marth, eds. Van Nostrand Reinhold, New York, NY.

Bynum, D. G., and N. F. Olson. 1982. Influence of curd firmness at cutting on Cheddar cheese yield and recovery of milk constituents. J. Dairy Sci. 65:2281-2290.

Caroli, A., P. Bolla, G. Pagnacco, M. Rampilli, and L. Degano. 1990. Repeatability of milk clotting aptitude evaluated by lactodynamographic analysis. J. Dairy Res. 57:141-142. 
Groeneveld, E. 1990. PEST User's Manual. Institute of Animal Husbandry and Animal Behaviour, Federal Agricultural Research Centre, Neustadt-Mariensee, Germany.

Hayes, J. F., K. F. Ng-Kwai-Hang, and J. E. Moxley. 1984. Heritability of milk casein and genetic and phenotypic correlations with production traits. J. Dairy Sci. 67:841-846.

Ikonen, T. 2000. Possibilities of genetic improvement of milk coagulation properties of dairy cows. Academic Diss., University of Helsinki, Department of Animal Science, Publications no. 49, http:// ethesis.helsinki.fi/julkaisu/maa/kotie/vk/ikonen/.

Ikonen, T., K. Ahlfors, R. Kempe, M. Ojala, and O. Ruottinen. 1999a. Genetic parameters for the milk coagulation properties and prevalence of noncoagulating milk in Finnish dairy cows. J. Dairy Sci. 82:205-214.

Ikonen, T., M. Ojala, and E.-L. Syväoja. 1997. Effects of composite casein and $\beta$-lactoglobulin genotypes on renneting properties and composition of bovine milk by assuming an animal model. Agric. Food Sci. Finl. 6:283-294.

Ikonen, T., O. Ruottinen, E.-L. Syväoja, K. Saarinen, E. Pahkala, and M. Ojala. 1999b. Effect of milk coagulation properties of herd bulk milks on yield and composition of Emmental cheese. Agric. Food Sci. Finl. 8:411-422.

Lindström, U. B., V. Antila, and J. Syväjärvi. 1984. A note on some genetic and non-genetic factors affecting clotting time of Ayrshire milk. Acta Agric. Scand. 34:349-355.
Lucey, J., and J. Kelly. 1994. Cheese yield. J. Soc. Dairy Technol. 47:1-14.

Marziali, A. S., and K. F. Ng-Kwai-Hang. 1986. Effects of milk composition and genetic polymorphism on coagulation properties of milk. J. Dairy Sci. 69:1793-1798.

McMahon, D. J., and R. J. Brown. 1984. Enzymatic coagulation of casein micelles: A review. J. Dairy Sci. 67:919-929.

Neumaier, A., and E. Groeneveld. 1998. Restricted maximun likelihood estimation of covariances in sparse linear models. Genet. Sel. Evol. 30:3-26.

Okigbo, L. M., G. H. Richardson, R. J. Brown, and C. A. Ernstrom. 1985. Variation in coagulation properties of milk from individual cows. J. Dairy Sci. 68:822-828.

Oloffs, K., H. Schulte-Coerne, K. Pabst, and H. O. Gravert. 1992. Die Bedeutung der Proteinvarianten für genetische Unterschiede in der Käsereitaughlichkeit der Milch. Züchtungskunde 64:20-26.

Riddell-Lawrence, S., and C. L. Hicks. 1989. Effect of curd firmness on stirred curd cheese yield. J. Dairy Sci. 72:313-321.

Schaar, J. 1984. Effects of $\kappa$-casein genetic variants and lactation number on the renneting properties of individual milks. J. Dairy Res. 51:397-406.

Tyrisevä, A.-M., T. Ikonen, and M. Ojala. 2003. Repeatability estimates for milk coagulation traits and non-coagulation of milk in Finnish Ayrshire cows. J. Dairy Res. 70:91-98. 